western United States, to so far south as Arizona, than at any time in the past fifteen years. A survey just completed by field men of the United States Bureau of Entomology shows that the eggs have survived the winter to a remarkably complete degree and now, with the sudden onset of hot weather, hatching is taking place with rapidity. The grasshoppers can be controlled by the proper distribution of bran baits poisoned with arsenic - a method that is usually adopted by farmers with monetary aids from the respective States or counties. With the fiscal affairs of the States none too good and some of them desperate, supplies of the necessary ingredients may be lacking in localities where infestation is greatest especially in South Dakota. Minnesota, on the other hand, with a lighter attack, has still funds in hand for financing a properly organised campaign.

\section{Genetical Society's Fund for Displaced Scientific Workers}

THE Genetical Society is raising a fund for the benefit of genetical workers, regardless of nationality, who have lost their positions as a result of racial or political discrimination, to be administered by the Society's committee, in co-operation with relief organisations. Grants will be made to as many individuals as the sum subscribed will warrant, in order to assist them to carry on research work in the British Empire. Subscriptions should be sent to Miss E. R. Saunders, 10 Newnham Terrace, Cambridge.

\section{A New Meteorite}

The Tass Agency has recently reported from Archangel that a new moteorite has fallen in the northern area of the U.S.S.R., 15 kilometres from the River Mezeni, in the vicinity of the village of Koslail. A piece of the meteorite weighing approximately two and a half tons was discovered near the meteorite itself. The Soviet Academy of Sciences (Meteorite Department) is making arrangements to investigate the new meteorite.

\section{Announcements}

IT is announced in the Times that Prof. Gilbert Murray has been elected chairman of the International Commission on Intellectual Co-operation and $\mathrm{Mme}$. Curie and Prof. Roccohave been elected vice-chairmen.

THe following have been elected officers of the Institution of Electrical Engineers for the year 1933-34: President, Mr. P. V. Hunter; VicePresident, Mr. R. P. Sloan; Treasurer, Mr. P. Rosling.

IT is announced in Science that Prof. James Franck, who recently resigned the chair of physics in the University of Göttingen, has been appointed for the coming academic year to be Speyer guest professor at the Johns Hopkins University.

ProF. D. P. D. WILKIE, professor of surgery in the University of Edinburgh, has been appointed a member of the Medical Research Council in succession to Mr. Wilfred Trotter, who retires in rotation on September 30 next, after four years' service.

Mr. E. J. Elford, borough engineer and surveyor of Wandsworth, past president of the Institution of Municipal and County Engineers, and chairman of the Building Divisional Council, has been elected to succeed Mr. M. F. G. Wilson as ehairman of the General Council of the British Standards Institution for the ensuing year.

IN NaTrRe of July 15, p. 96 , the date of the London session of the International Congress of Anthropological and Ethnological Sciences is wrongly announced as 1933. It should be 1934, as it is arranged so as to divide the interval between the Prehistoric Congresses of 1932 and 1936, and to fall in the same year as the European session of the International Congress of Americanists, namely at Seville in 1934.

Referring to the article entitled "New Science Laboratories in Aligarh" in Nature of July 15, Messrs. Adam Hilger Ltd. inform us that they have, in the past few years, supplied to the Aligarh Muslim University quartz spectrographs, an infra-red spectrometer, a Michelson interferometer and other apparatus, and that they have now under construction for the Physical Laboratory a 2-metre vacuum grating spectrograph of high dispersion in which the grating is used at nearly grazing incidence.

THE Institution of Electrical Engineers has published an index to vols. 60-69 (1922-1931) of its Journal. This is the sixth ten-yearly index it has published since 1872. These indexes are of great value for reference.

Applications are invited for the following appointments, on or before the dates mentioned :-A chief lecturer, and a lecturer in mechanical and civil engineering at the Rotherham College of Technology and Art-The Director of Education, Education Offices, Rotherham (July 29). An assistant science and mathematics master at the Exeter Junior Technical College-The Secretary for Education, 39, Southernhay West, Exeter (July 29). A head of the Department of Electrical Engineering and Physics at the Leeds Technical College-The Director of Education, Education Offices, Calverley Street, Leeds (July 31). A demonstrator in zoology at the University of Leeds-The Registrar (Aug. 5). A reader in physics at the University of Dacea, IndiaThe Registrar, University of Dacca, P.O. Ramna, Dacca, East Bengal (Aug. 31). A university reader in pharmaceutics at the College of the Pharmaceutical Society-The Academic Registrar, University of London, S.W.7 (Sept. 14). A teacher of science and a domestic science mistress at the Chatham Day Technical School for Girls - The District Education Officer, 15, New Road Avenue, Chatham. 